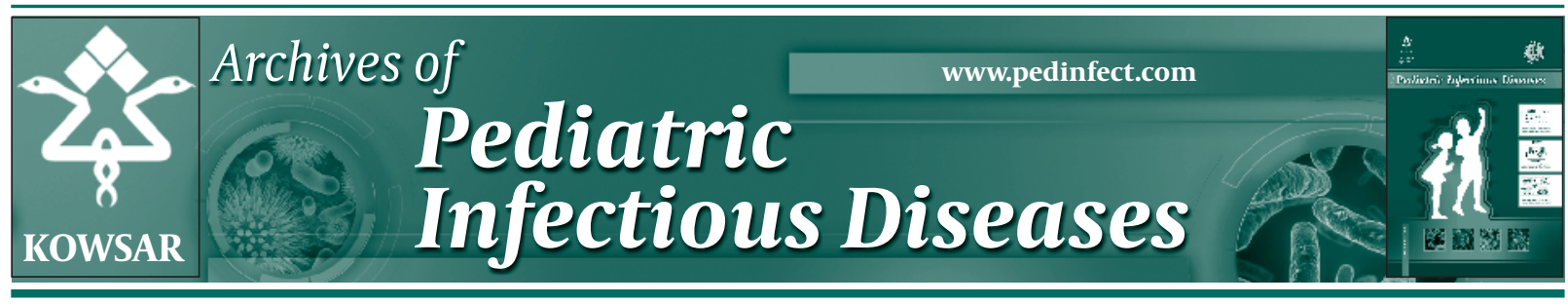

\title{
Urinary Tumor Necrosis Factor-Alpha a Good Indicator for Inflammatory Response in Pyelonephritis
}

\author{
Masoumeh Mohkam ${ }^{1,}$,, Sedigheh Rafiei Tabatabaei ${ }^{1}$, Fahimeh Asgarian ${ }^{1}$, Shahnaz Armin ${ }^{1}$, \\ Alireza Fahimzad ${ }^{1}$, Mostafa Sharifian ${ }^{1}$, Reza Dalirani ${ }^{1}$ \\ ${ }^{1}$ Pediatric Infections Research Center, Shahid Beheshti University of Medical sciences, Tehran, IR Iran \\ * Corresponding author: Masoumeh Mohkam, Pediatric Infections Research Center, Shahid Beheshti University of Medical sciences, Tehran, IR Iran. Tel.: \\ +98-9121968520, Fax: +98-22227033, E-mail: mohkam@pirc.ir
}

\begin{abstract}
A B S T R A C T
Background: TNF- $\alpha$ is one of the most potent cytokines in proinflammatory reactions.

Objectives: This article contributes to evaluate the correlation between urinary TNF- $\alpha$ and inflammatory response markers in children with acute pyelonephritis.

Patients and Methods: This cross sectional study, was performed on children with acute pyelonephritis. Fresh random urine samples were obtained before treatment of pyelonephritis. Urine samples were tested for TNF- $\alpha$ and creatinine. We also evaluated our patients with routine biochemical studies.

Results: One hundred and twenty children with acute pyelonephritis were evaluated. Urinary TNF- $\alpha / \mathrm{Cr}$ was $0.0051 \pm 0.00083 \mathrm{Pg} / \mathrm{g}$ creatinine. The authors found out a significant difference in urinary TNF- $\alpha / \mathrm{Cr}$ between patients who have normal and abnormal levels of urine leukocytes, urine protein, urine culture, erythrocyte sedimentation rate and C- reactive protein. This study revealed a significant correlation between urinary TNF-alpha and urine WBC $(r=0.36, P$ value $=0.02)$, ESR $(r=0.75, P$ value $=0.03)$ and CRP $(r=$ 0.58 , P value $=0.02$.

Conclusions: We concluded that urinary TNF- $\alpha / \mathrm{Cr}$ might be a good indicator for inflammatory response in children with acute pyelonephritis.
\end{abstract}

Keywords: Tumor Necrosis Factor-alpha; Pediatrics; Pyelonephritis

Copyright ( @ 2013, Pediatric Infections Research Center

Article type: Research Article; Received: 21 Nov 2012, Revised: 20 Dec 2012, Accepted: 01 Jan 2013; DOI: 10.5812/pedinfect.9114

Implication for health policy/practice/research/medical education:

Urinary tract infection (UTI) is one of the most commonest infections in children. Current researches try to detect the infection and differentiate between upper and lower UTI by evaluation of urinary proteins.

Please cite this paper as:

Mohkam M, Rafiei Tabatabaei S, Asgarian F, Armin S, Fahimzad A, Sharifian M. Urinary Tumor Necrosis Factor-Alpha a Good Indicator for Inflammatory Response in Pyelonephritis. Arch Pediatr Infect Dis.2013;1(2): 87-91. DOI: 10.5812/pedinfect.9114

Copyright @ 2013, Pediatric Infections Research Center

This is an Open Access article distributed under the terms of the Creative Commons Attribution License (http://creativecommons.org/licenses/by/3.0), which permits unrestricted use, distribution, and reproduction in any medium, provided the original work is properly cited. 


\section{Background}

Urinary tract infection (UTI) is by far the most common serious bacterial infection in febrile young infants (1). UTI may cause inflammation of the renal parenchyma and may lead to impairment in renal function and scar formation. Among the immunocytes involved in the defense against UTI, granulocytes play a crucial role $(2,3)$. Now a days analysis of urinary inflammatory cytokines and mediators are important areas for nephrologic researches. Cytokines are small proteins which are important for the orchestration of inflammatory processes (4). The results of previous researches suggest that urinary cytokines may be elevated in urinary tract infections and may play a key role in defining pyelonephritis (5-9). TNF- $\alpha$ is one of the mostimportant and most potent cytokines in proinflammatory reactions. Role of TNF- $\alpha$ in monitoring the therapeutic response to BCG in bladder cancer (10), in evaluation of pediatric febrile infections (11), in shistosoma haematobium-induced urinary-tract morbidity $(12,13)$, in glomerulonephritis (14-16) and in pathogenesis of allograft rejection (17) has been reported before. Recent studies show the role of TNF-a in apoptosis and pathogenesis of pediatrics renal diseases $(18,19)$, in the pathogenesis and progression of renal injury in diabetes mellitus, as an accurate marker for diagnosis of acute pyelonephritis $(20,21)$ and as a pathogenic indicator of multidrug resistance $E$. coli in urosepsis (22). A great majority of these studies have been done on serum level of TNF- $\alpha$; however, few researchers have studied the changes in the urinary level of TNF- $\alpha$ in UTI. Some of these studies have reported no change in the urinary level of TNF- $\alpha$ in children with UTI $(23,24)$ and some showed an increased level of urinary TNF- $\alpha$ in pediatric UTI $(25,26)$.

\section{Objectives}

This article aims to evaluate the correlation of urinary TNF- $\alpha$ with inflammatory response markers in children with acute pyelonephritis documented by dimercaptosuccinic acid scintigraphy (DMSA).

\section{Patients and Methods}

This cross sectional study was conducted from March 2006 to April 2011 on children with acute pyelonephri- tis admitted in Mofid children's hospital. The diagnosis of acute pyelonephritis was confirmed based upon standard criteria [ fever (more than $38^{\circ} \mathrm{C}$ ), abdominal pain, anorexia, dysuria, leukocyturia (more than $5 / \mathrm{Hpf}$ ), positive urine culture, increased ESR (erythrocyte sedimentation rate $>20 \mathrm{~mm} / \mathrm{hr}$ ), positive CRP (C- reactive protein $\geq$ $1+)$ and abnormal DMSA scan findings in favor of pyelonephritis (27). Our patients have been previously healthy with no signs of any nephrologic or urologic problems. We excluded patients with recent history of antibiotic consumption, (during previous 7 days) and patients with renal insufficiency or any kind of known kidney or urinary tract disorders or other accompanying infections. Fresh random urine samples were obtained at admission and were tested for TNF- $\alpha$ (ELISA colorimetric, SANQUINE, USA) and creatinine (Jaffe reaction, auto analyzer, RA 1000). All patients were treated with $75 \mathrm{mg} / \mathrm{kg} /$ day intravenous ceftriaxone with or without $15 \mathrm{mg} / \mathrm{kg} /$ day intravenous amikacin based on antibiogram results). We also evaluated our patients with routine biochemical studies and inflammatory markers like erythrocyte sedimentation rate (ESR) and C- reactive protein (CRP). The ethics committee of the Shahid Beheshti medical university and pediatric infectious research center approved this study.

Data were expressed as mean \pm SD. Mann-Whitney U test and Pearson's correlation coefficient was used for analysis. Statistic test was two-tailed and was considered significant when $\mathrm{P} \leq 0.05$.

\section{Results}

One hundred and twenty children (84\% female) with acute pyelonephritis, mean age $38 \pm 35$ months were evaluated. The demographic data and clinical features of study group are shown in Tables 1 and 2 . Urinary TNF- $\alpha / \mathrm{Cr}$ on admission was $0.0051 \pm 0.00083 \mathrm{Pg} / \mathrm{g}$ creatinine.

This research revealed a significant correlation between urinary TNF-alpha and urine $\mathrm{WBC}(\mathrm{r}=0.36$; Pvalue $=0.02)$, $\operatorname{ESR}(\mathrm{r}=0.75 ; \mathrm{P}$ value $=0.03)$ and $\operatorname{CRP}(\mathrm{r}=0.58 ; \mathrm{P}$ value $=$ 0.02). Furthermore, our study showed a significant difference between the level of urinary TNF- $\alpha / \mathrm{Cr}$ in patients with normal and abnormal urine leukocytes, urine protein, urine specific gravity, urine culture, ESR and CRP (all P values were < 0.001; See Table 3).

Table 1. Demographic Data of Study Group (mean, Standarddeviation)

\begin{tabular}{|c|c|c|c|c|}
\hline & Minimum & Maximum & Mean & SD \\
\hline Age, mon & 1 & 132 & 38.14 & 34.96 \\
\hline Body weight, Kg & 3 & 47 & 13.81 & 9.46 \\
\hline White blood cell, No/micL & 3200 & 29000 & 15830 & 10000 \\
\hline ESR, mm/hr & 2 & 102 & 45.16 & 31.47 \\
\hline CRP, mg/dL & 2 & 80 & 45 & 20 \\
\hline Urine WBC, No/micL & 2 & 30 & 19.45 & 10.84 \\
\hline Urine TNF- $\alpha / \mathrm{Cr}, \mathrm{Pg} / \mathrm{g}$ creatinine & 0.0041 & 0.064 & 0.005114 & 0.000834 \\
\hline
\end{tabular}




\begin{tabular}{ll}
\hline Table 2. Clinical and Paraclinical Features of Study Group \\
\hline Clinical features & Frequency, \% \\
\hline Hematuria & 2.6 \\
\hline Fever & 51.5 \\
\hline Dysuria & 12.6 \\
\hline Vomiting & 13.9 \\
\hline Abdominalpain & 7.6 \\
\hline Abnormal CRP & 40 \\
\hline Abnormal ESR & 80 \\
\hline Leukocyturia & 100 \\
\hline Proteinuria & 30 \\
\hline Nitrite positive & 36.2 \\
\hline Positive urine culture & 85.7 \\
\hline Ecoli & 69.2 \\
\hline Klebsiella & 9.8 \\
\hline Enterococ & 1.7 \\
\hline Pseudomonas & 3 \\
\hline Enterococ & 2 \\
\hline
\end{tabular}

Table 3. Comparison of TNF- $\alpha / C r$ in Children With Pyelonephritis With Different Levels of Other Inflammatory Markers.

\begin{tabular}{|lll|}
\hline & $\begin{array}{l}\text { Urine TNF- } \alpha / \mathrm{Cr}(\mathrm{pg} / \mathrm{g} ; \\
\text { mean } \pm \text { SD })\end{array}$ & PValue \\
\hline Urine leukocytes & & $<0.001$ \\
\hline Abnormal & $0.0045 \pm 0.0009$ & \\
\hline Normal & $0.0015 \pm 0.0006$ & $<0.001$ \\
\hline Urine protein & & \\
\hline Abnormal & $0.0039 \pm 0.0008$ & $<0.001$ \\
\hline Normal & $0.0016 \pm 0.0009$ & \\
\hline Urine specific & \\
gravity & \\
\hline Abnormal & $0.0043 \pm 0.0007$ & $<0.001$ \\
\hline Normal & $0.0013 \pm 0.0005$ & \\
\hline Urine culture & \\
\hline Positive & $0.0039 \pm 0.0009$ & $<0.001$ \\
\hline Negative & $0.0015 \pm 0.0009$ & \\
\hline ESR & \\
\hline Abnormal & $0.0040 \pm 0.0003$ & $<0.001$ \\
\hline Normal & $0.0014 \pm 0.0004$ & \\
\hline CRP & & \\
\hline Abnormal & $0.0039 \pm 0.0002$ & \\
\hline Normal & $0.0014 \pm 0.0006$ & \\
\hline
\end{tabular}

It means that the level of urinary TNF- $\alpha / \mathrm{Cr}$ were significantly higher in patients with abnormal urine leukocytes, urine protein, urine culture, ESR and CRP than who have normal range of these examinations in children with acute pyelonephritis.

\section{Discussion}

In the present study, we sought to gain more insight into the correlation of urinary TNF- $\alpha$ with inflammatory factors in children with acute pyelonephritis. Our research revealed a significant correlation between Urinary TNF-alpha and urine WBC $(r=0.36), \operatorname{ESR}(r=0.75)$ and CRP $(\mathrm{r}=0.58)$. Cytokines and cytokine receptors are involved in the systemic and local inflammatory response in patients with urinary tract infections (28). TNF- $\alpha$ is rapidly recruited to the bladder in urinary tract infection and contributes directly to the innate defense against various viral and bacterial infections (29). Biyikli et al. showed that TNF- $\alpha$, renal tissue malondialdehyde and myeloperoxidase levels are elevated in rats with acute and chronic pyelonephritis (30) and Wolfs determined the role of TNF- $\alpha$ in immunosurveillance during inflammation at the site in which ascending bacteria enter the kidney tissue, the collecting ducts and the distal part of the nephron (31). Florquin reported that the production of tubular epithelial urokinase receptor was strongly upregulated after stimulation with TNF- $\alpha$ during urosepsis (32). Author's previous study reported that urinary TNF$\alpha$-creatinine ratio was significantly increased in pediatric acute pyelonephritis and it decreased after appropriate therapy (25). Tullus showed that urinary soluble TNF receptor levels were higher during acute pyelonephritis (33) and Davidoff showed U TNF- $\alpha$ is significantly elevated in patients with microhematuria and cystitis compared to normal (26). Sadeghi et al. revealed an increased level of urinary cytokines like TNF- $\alpha$ during bacteriuria in kidney transplant patients (34).

Regardless of these results Dariusz reported that concentrations of TNF- $\alpha$ in serum and urine were below the limit of detection in the vast majority of controls and pyelonephritic patients, and no significant differences were found between the two groups; Kim et al's study showed the same results (24-25). Larger studies of the role of this factor in pyelonephritis and the correlation between its level and other investigations of pyelonephritic patients such as imaging studies have not been performed so far. According to our results, there is a significant correlation between the level of urinary TNF- $\alpha / \mathrm{Cr}$ and inflammatory markers such as ESR, CRP, urinary leukocytes and even urine culture in patients with acute pyelonephritis. De Man has reported the correlation between the level of circulatory tumor necrosis factor with fever, increased ESR and CRP in acute symptomatic UTI (35) but few studies have been performed on correlation between urinary TNF- $\alpha$ and inflammatory markers of pyelonephritis.

Ultimately the results of these studies might reveal the efficacy of urinary TNF- $\alpha / \mathrm{Cr}$ in anticipation of the inflammatory factors in pyelonephritis. Our findings have addressed the real role of urinary TNF- $\alpha$ in better and faster diagnosis of pyelonephritis and for follow up of these pa- 
tients. The authors recommend more and wide researches to get more information for better circumlocution of this fact.

\section{Acknowledgements}

We would like to acknowledge the skilful technical assistance of Pediatric Infectious Research Center staff.

\section{Authors' Contribution}

None declared.

\section{Financial Disclosure}

None declared.

\section{Funding/Support}

None declared.

\section{References}

1. Zorc JJ, Levine DA, Platt SL, Dayan PS, Macias CG, Krief W, et al Clinical and demographic factors associated with urinary tract infection in young febrile infants. Pediatrics. 2005;116(3):644-8.

2. Godaly G, Proudfoot AE, Offord RE, Svanborg C, Agace WW. Role of epithelial interleukin-8 (IL-8) and neutrophil IL-8 receptor A in Escherichia coli-induced transuroepithelial neutrophil migration. Infect Immun. 1997;65(8):3451-6.

3. Haraoka M, Hang L, Frendeus B, Godaly G, Burdick M, Strieter R, et al. Neutrophil recruitment and resistance to urinary tract infection. JInfect Dis. 1999;180(4):1220-9.

4. van der Poll T, Lowry SF. Tumor necrosis factor in sepsis: mediator of multiple organ failure or essential part of host defense? Shock 1995;3(1):1-12.

5. Sandberg T, Bergmark J, Hultberg B, Jagenburg R, Trollfors B. Diag nostic potential of urinary enzymes and beta 2-microglobulin in acute urinary tract infection. Acta Med Scand. 1986;219(5):489-95.

6. Mohkam M, Karimi A, Karimi H, Sharifian M, Armin S, Dalirani R, et al. Urinary interleukin-8 in acute pyelonephritis of children: a before-after study. Iran J Kidney Dis. 2008;2(4):193-6.

7. Skalova S. The diagnostic role of urinary N-acetyl-beta-D-glucosaminidase (NAG) activity in the detection of renal tubular impairment. Acta Medica (Hradec Kralove). 2005;48(2):75-80.

8. Mohkam M, Karimi A, Habibian S, Sharifian M. Urinary N-acetylbeta-D-glucosaminidase as a diagnostic marker of acute pyelonephritis in children. Iran J Kidney Dis. 2008;2(1):24-8.

9. Sharifian M, Anvaripour N, Karimi A, Fahimzad A, Mohkam M, Dalirani R, et al. The role of dexamethasone on decreasing urinary cytokines in children with acute pyelonephritis. Pediatr Nephrol. 2008;23(9):1511-6.

10. Jackson AM, Alexandrov AB, Prescott S, James K. Production of urinary tumour necrosis factors and soluble tumour necrosis factor receptors in bladder cancer patients after bacillus Calmette-Guerin immunotherapy. Cancer Immunol Immunother 1995;40(2):119-24.

11. Lin SJ, Huang JL. Circulating interleukin (IL)-1 beta, IL-6 and tumor necrosis factor-alpha in children with febrile infection--a comparison with C-reactive protein. Asian Pac J Allergy Immunol. 1998;16(2-3):105-9.

12. Wamachi AN, Mayadev JS, Mungai PL, Magak PL, Ouma JH, Magambo JK, et al. Increased ratio of tumor necrosis factoralpha to interleukin-10 production is associated with Schistosoma haematobium-induced urinary-tract morbidity. J Infect Dis 2004;190(11):2020-30.

13. King CL, Malhotra I, Mungai P, Wamachi A, Kioko J, Muchiri E, et al. Schistosoma haematobium-induced urinary tract morbidity cor- relates with increased tumor necrosis factor-alpha and diminished interleukin-10 production. J Infect Dis. 2001;184(9):1176-82.

14. Honkanen E, von Willebrand E, Teppo AM, Tornroth T, Gronhagen-Riska C. Adhesion molecules and urinary tumor necrosis factor-alpha in idiopathic membranous glomerulonephritis. Kidney Int.1998;53(4):909-17.

15. Kacprzyk F, Chrzanowski W. [Tumor necrosis factor (TNF) and interleukin-6 (IL-6) in patients with glomerulonephritis]. Pol Arch Med Wewn. 1996;96(3):224-33

16. Ozen S, Saatci U, Tinaztepe K, Bakkaloglu A, Barut A. Urinary tumor necrosis factor levels in primary glomerulopathies. Nephron.1994;66(3):291-4.

17. McLaughlin PJ, Aikawa A, Davies HM, Ward RG, Bakran A, Sells RA et al. Evaluation of sequential plasma and urinary tumor necrosis factor alpha levels in renal allograft recipients. Transplantation. 1991;51(6):1225-9.

18. Chevalier RL. Obstructive nephropathy: towards biomarker discovery and gene therapy. Nat Clin Pract Nephrol. 2006;2(3):157-68.

19. Misseri R, Meldrum KK. Mediators of fibrosis and apoptosis in obstructive uropathies. Curr Urol Rep. 2005;6(2):140-5.

20. Navarro JF, Mora C, Muros M, Garcia J. Urinary tumour necrosis factor-alpha excretion independently correlates with clinica markers of glomerular and tubulointerstitial injury in type 2 diabetic patients. Nephrol Dial Transplant. 2006;21(12):3428-34.

21. Gurgoze MK, Akarsu S, Yilmaz E, Godekmerdan A, Akca Z, Ciftci I, et al. Proinflammatory cytokines and procalcitonin in children with acute pyelonephritis. Pediatr Nephrol. 2005;20(10):1445-8.

22. Bristianou M, Panagou C, Adamis T, Raftogiannis M, Antonopoulou A, Chrisofos M, et al. The impact of multidrug resistance on the pathogenicity of Escherichia coli: an experimental study. Int J Antimicrob Agents. 2008;31(3):216-23.

23. Olszyna DP, Prins JM, Buis B, van Deventer SJ, Speelman P, van der Poll T. Levels of inhibitors of tumor necrosis factor alpha and interleukin 1beta in urine and sera of patients with urosepsis. Infect Immun. 1998;66(8):3527-34.

24. Kim KH, Hong YM, Kim GH. Urinary interleukin-1beta levels in children with urinary tract infection. J Korea Pediatr Soci. 1997;40(7):981-990.

25. Mohkam M, Asgarian F, Fahimzad A, Sharifian M, Dalirani R, Abdollah Gorgi F. Diagnostic potential of urinary tumor necrosis factor-alpha in children with acute pyelonephritis. Iran J Kidney Dis. 2009;3(2):89-92.

26. Davidoff R, Yamaguchi R, Leach GE, Park E, Lad PM. Multiple urinary cytokine levels of bacterial cystitis. J Urol. 1997;157(5):1980-5.

27. Avner ED, Harmon WE, Niaudet P. Pediatric Nephrology. 6th ed New York: Lippincott Williams and Willkins 2009.

28. Jacobson SH, Lu Y, Brauner A. Soluble interleukin-6 receptor, interleukin-10 and granulocyte colony-stimulating factor in acute pyelonephritis: relationship to markers of bacterial virulence and renal function. Nephron.1998;80(4):401-7.

29. Engel D, Dobrindt U, Tittel A, Peters P, Maurer J, Gutgemann I et al. Tumor necrosis factor alpha- and inducible nitric oxide synthase-producing dendritic cells are rapidly recruited to the bladder in urinary tract infection but are dispensable for bacterial clearance. Infect Immun. 2006;74(11):6100-7.

30. Biyikli NK, Tugtepe H, Sener G, Velioglu-Ogunc A, Cetinel S, Midillioglu $\mathrm{S}$, et al. Oxytocin alleviates oxidative renal injury in pyelonephritic rats via a neutrophil-dependent mechanism. Peptides. 2006;27(9):2249-57.

31. Wolfs TG, Buurman WA, van Schadewijk A, de Vries B, Daemen MA Hiemstra PS, et al. In vivo expression of Toll-like receptor 2 and 4 by renal epithelial cells: IFN-gamma and TNF-alpha mediated upregulation during inflammation. J Immunol.2002;168(3):1286-93.

32. Florquin S, van den Berg JG, Olszyna DP, Claessen N, Opal SM Weening JJ, et al. Release of urokinase plasminogen activator receptor during urosepsis and endotoxemia. Kidney Int 2001;59(6):2054-61.

33. Tullus K, Escobar-Billing R, Fituri O, Lu Y, Brauner A. Soluble receptors to tumour necrosis factor and interleukin-6 in urine during acute pyelonephritis. Acta Paediatr.1997;86(11):1198-202.

34. Sadeghi M, Daniel V, Naujokat C, Wiesel M, Hergesell O, Opelz G 
Strong inflammatory cytokine response in male and strong antiinflammatory response in female kidney transplant recipients with urinary tract infection. Transpl Int. 2005;18(2):177-85.

35. De Man P, Jodal U, Van Kooten C, Svanborg C. Bacterial adher- ence as a virulence factor in urinary tract infection. APMIS. 1990;98(12):1053-60. 